\title{
Resistance to thyroid hormone due to a novel mutation of thyroid hormone receptor beta gene
}

\author{
Jae Hee Lee, MD, \\ Eun Young Kim, MD, PhD \\ Department of Pediatrics, Chosun \\ University School of Medicine, \\ Gwangju, Korea
}

\begin{abstract}
Resistance to thyroid hormone $(\mathrm{RTH})$ is a rare inherited syndrome characterized by diminished response of the target tissue to thyroid hormone caused, in the majority of cases, by mutation of the thyroid hormone receptor beta (THR $\beta)$ gene. Despite elevated serum levels of free thyroid hormones and thyroid stimulating hormone (TSH), the paucity of symptoms and signs of thyroid dysfunction suggest RTH. We report the case of a 9-year-old girl with goiter. Her thyroid function tests showed increased serum levels of free thyroxine, triiodothyronine, and TSH. The genetic analysis of THR $\beta$ confirmed a novel mutation in exon 9; this was a heterozygous C-to-T change in the 327th codon, substituting threonine for isoleucine (T327I).
\end{abstract}

Keywords: Thyroid hormone resistance syndrome, Mutation, Thyroid hormone receptors beta

\section{Introduction}

Resistance to thyroid hormone (RTH) is a rare inherited syndrome characterized by diminished response of target tissue to thyroid hormone. The patients with RTH have elevated serum levels of free thyroxine (fT4) and triiodothyronine (T3) in the absence of thyroidstimulating hormone (TSH) suppression ${ }^{1)}$. The prevalence of RTH is approximately 1:40,000 births $^{2)}$. Its incidence is equal in males and females. The inheritance is autosomal dominant. Approximately $85 \%$ of the cases have a mutation in the thyroid hormone receptor beta $(T H R \beta)$ gene, and more than 100 mutations have been discovered. The clinical manifestations vary. Goiter is the most common clinical finding. Other symptoms and signs include sinus tachycardia, learning disabilities, developmental delay, and delayed bone age ${ }^{3)}$.

Here, we report the case of a child, who presented with goiter, with RTH due to a novel mutation in the THR $\beta$ gene.

\section{Case report}

A 9-year-old girl was referred to Chosun University Hospital because of abnormal thyroid function test results. She noted an asymptomatic goiter 7 days ago. The results of her thyroid function tests revealed that the serum levels of fT4 and TSH were $7.12 \mathrm{ng} / \mathrm{dL}$ and $12.4 \mathrm{uIU} /$ $\mathrm{mL}$, respectively.

She was born at full term and had no remarkable medical history of hyperactivity or learning problem. She had average performance at school. There was no family history of thyroid disorders. Her physical examination revealed the following: height, $141 \mathrm{~cm}$ (75th-90th percentiles); weight, $37 \mathrm{~kg}$ (75th-90th percentiles); pulse rate, 102 beats/min (average rate, $70-110$ beats/min); blood pressure, $110 / 70 \mathrm{mmHg}$; and body temperature, $37.3^{\circ} \mathrm{C}$. The thyroid gland was diffusely enlarged. There was no trill or exophthalmos.

The complete blood count and blood chemistry examination showed normal results. Her thyroid function test results revealed that the serum levels of fT4, T3, and THS were $9.89 \mathrm{ng} / \mathrm{dL}$

Fax: +82-62-227-2904

E-mail: sskey@chosun.ac.kr 
(reference range, $0.7-1.8 \mathrm{ng} / \mathrm{dL}$ ), $403.2 \mathrm{ng} / \mathrm{dL}$ (reference range, 60-190 ng/dL), and $11.82 \mu \mathrm{IU} / \mathrm{mL}$ (reference range, $0.25-4.0$ $\mu \mathrm{IU} / \mathrm{mL}$ ), respectively. She tested negative for antithyroglobulin antibody, antimicrosome antibody, and TSH receptor antibody. Her serum levels of prolactin, luteinizing hormone, and folliclestimulating hormone were within the reference range. She underwent a thyrotropin-releasing hormone (TRH) stimulation test. After receiving $200 \mu \mathrm{g} / \mathrm{m}^{2}$ of TRH, the TSH showed a normal response (TSH at baseline, $8.38 \mu \mathrm{IU} / \mathrm{mL}$; TSH at 15 minutes, $17.36 \mu \mathrm{IU} / \mathrm{mL}$; TSH at 30 minutes, $21.70 \mu \mathrm{IU} / \mathrm{mL}$; $\mathrm{TSH}$ at 60 minutes, $19.42 \mu \mathrm{IU} / \mathrm{mL}$; TSH at 90 minutes, 17.89 $\mu \mathrm{IU} / \mathrm{mL}$; TSH at 120 minutes, $4.95 \mu \mathrm{IU} / \mathrm{mL}$ ).

The $99 \mathrm{~m}$ Technetium thyroid scan revealed diffuse enlargement with increased uptake in both lobes of thyroid gland; no cold nodules were observed (Fig. 1). A magnetic resonance imaging scan showed no abnormalities of the pituitary.

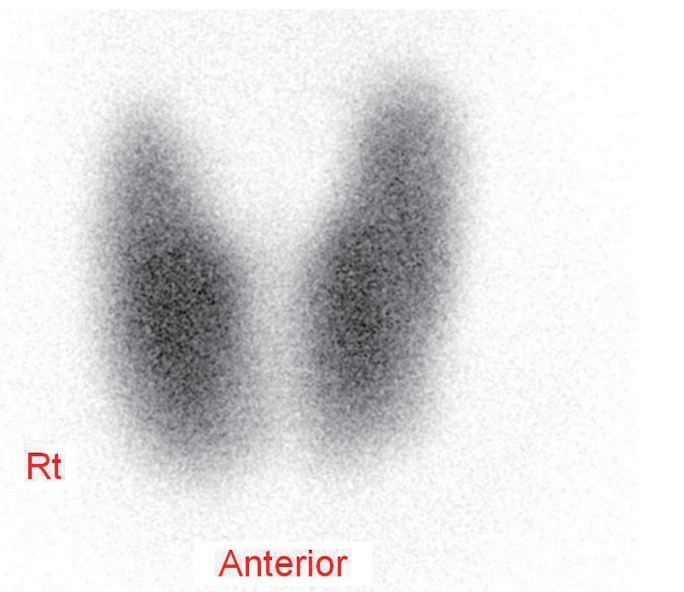

Fig. 1. A 99m Technetium thyroid scan shows diffuse marked enlargement with increased uptake in both the thyroid glands.
A polymerase chain reaction sequencing of the THR $\beta$ gene of the patient showed a novel mutation in exon 9. This was a heterozygous C-to- $\mathrm{T}$ transition mutation in the 327 th codon, substituting threonine for isoleucine (c.980C>T; p.Thr327Ile) (Fig. 2). Analysis with the software program, Polyphen and SIFT indicated that this sequence change is probably damaging. Her parents were also examined for this mutation; the same mutation was found in her father, who was asymptomatic. The patient remained asymptomatic and did not need any treatment at the 12-month follow-up.

\section{Discussion}

RTH is an inherited syndrome, first described by Refetoff et al. ${ }^{4)}$ in 1967, characterized by refractoriness of target tissues to thyroid hormone.

Thyroid hormone receptors (TRs) are ligand-dependent transcription factors that mediate the activity of T3. TRs are encoded by 2 genes, designated as $\alpha$ and $\beta$ genes. Four different TRs have been identified: $\alpha-1, \alpha-2, \beta-1$ and $\beta-2^{3)}$. Each TR isoform has tissue specific expression that varies with the stage of development. Thyroid hormone receptor alpha-1 (THRa1) is highly expressed in the heart, bone, and brain; THR $\beta 1$ is more abundant in the liver, kidney, and thyroid; and THR $\beta 2$ expression is limited to the pituitary, hypothalamus, and ear ${ }^{5)}$. About $90 \%$ of RTH patients have mutations in the THR $\beta$ gene, and at least 128 mutations in this gene have been reported thus $\mathrm{far}^{3)}$. RTH without mutations occurs in approximately $10 \%$ of the cases. Recently, mutations in the THR $\alpha$ gene have been identified in some case reports ${ }^{6,7)}$. These patients show different phenotypes from the RTH patients with THR $\beta$

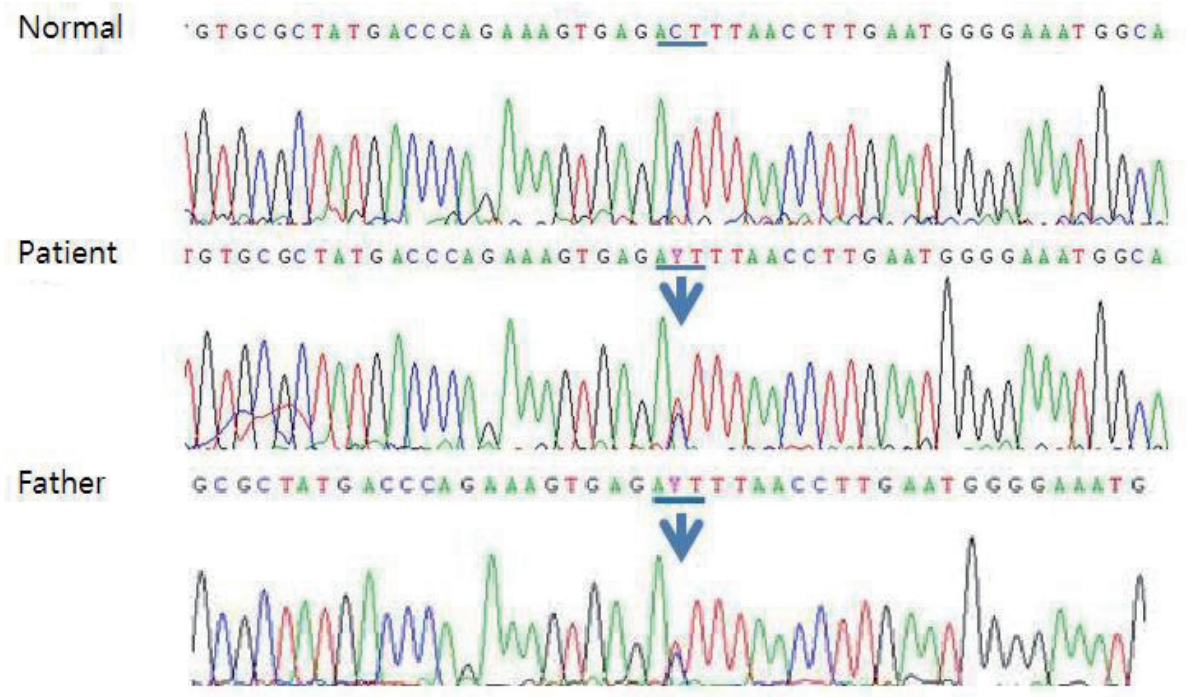

Fig. 2. Sequence analysis of the thyroid hormone receptor beta (THRß) gene showing a heterozygous mutation in exon 9, substituting threonine for isoleucine (c.980C>T;p.Thr327lle), in the patient and her father. 
gene mutation, with relatively low serum T4 and high serum T3 levels, growth and developmental retardation, delayed bone development, and constipation.

Including our case, 11 cases of RTH have been reported in the literature in $\mathrm{Korea}^{8}$; 8 patients had known missense mutations in the THR $\beta$ gene, 2 patients had novel mutations_insertion and missense mutation (our case) in the THR $\beta$ gene ${ }^{9)}$ and 1 patient had no mutation ${ }^{10)}$.

Familial occurrence of RTH has been documented in approximately $75 \%$ of cases, and approximately $20 \%$ of the patients are de novo cases ${ }^{3)}$.

The hallmark of RTH is the paucity of clinical features of thyroid dysfunction despite increased serum T4 and T3 levels. When present, the clinical feature is highly heterogeneous owing to variable degrees of peripheral resistance in different patients, as well as variable resistance in different tissues within a single individual ${ }^{11)}$. The clinical features are goiter, tachycardia, hyperactivity, developmental delay, and learning disability. The diagnosis of RTH is based on clinical findings, standard laboratory tests, and genetic studies. The finding of elevated serum thyroid hormone levels association with unsuppressed TSH usually leads to the diagnosis ${ }^{3)}$.

It is important to accurately identify RTH, as misdiagnosis could lead to unnecessary treatments such as thyroidectomy or radioiodine. Amor et al. ${ }^{12)}$ reported that $19 \%$ of the patients had undergone some type of thyroidal ablative therapy before diagnosis, similar to a result published 15-20 years earlier. Treatment is not required in most patients because the elevated thyroid hormones levels compensate for the partial tissue resistance. Betaadrenergic blockers relieve sinus tachycardia. Supraphysiological doses of liothyronine, given as a single dose every other day, are effective in reducing goiter without causing side effects ${ }^{13)}$. In children, particular attention must be paid to growth, bone maturation and mental development ${ }^{3)}$.

In conclusion, we report a novel mutation in the THR $\beta$ gene in a 9-year-old girl. RTH is very rare and must be considered in patients who present with goiter and increased thyroid hormone levels with unsuppressed TSH.

\section{Conflict of interest}

No potential conflict of interest relevant to this article was reported.

\section{References}

1. Weiss RE, Refetoff S. Resistance to thyroid hormone. Rev Endocr Metab Disord 2000;1:97-108.

2. Lafranchi SH, Snyder DB, Sesser DE, Skeels MR, Singh $\mathrm{N}$, Brent GA, et al. Follow-up of newborns with elevated screening T4 concentrations. J Pediatr 2003;143:296-301.

3. Refetoff S, Dumitrescu AM. Syndromes of reduced sensitivity to thyroid hormone: genetic defects in hormone receptors, cell transporters and deiodination. Best Pract Res Clin Endocrinol Metab 2007;21:277-305.

4. Refetoff S, DeWind LT, DeGroot LJ. Familial syndrome combining deaf-mutism, stuppled epiphyses, goiter and abnormally high PBI: possible target organ refractoriness to thyroid hormone. J Clin Endocrinol Metab 1967;27:279-94.

5. Rebaï M, Kallel I, Rebai A. Genetic features of thyroid hormone receptors. J Genet 2012;91:367-74.

6. Moran C, Schoenmakers N, Agostini M, Schoenmakers E, Offiah A, Kydd A, et al. An adult female with resistance to thyroid hormone mediated by defective thyroid hormone receptor a. J Clin Endocrinol Metab 2013;98:4254-61.

7. van Mullem AA, Visser TJ, Peeters RP. Clinical consequences of mutations in thyroid hormone receptor- $\alpha 1$. Eur Thyroid J 2014;3:17-24.

8. Kim HK, Kim D, Yoo EH, Lee JI, Jang HW, Tan AH, et al. A case of resistance to thyroid hormone with thyroid cancer. J Korean Med Sci 2010;25:1368-71.

9. Kim JH, Park TS, Baek HS, Kim GH, Yoo HW, Park JH. A newly identified insertion mutation in the thyroid hormone receptor-beta gene in a Korean family with generalized thyroid hormone resistance. J Korean Med Sci 2007;22:5603.

10. Seo JY, Yoon IS, Yoo JH, Ahn SY, Jeong HL, Shin CH, et al. A case of thyroid hormone resistance (RTH). J Korean Soc Pediatr Endocrinol 2005;10:100-4.

11. Beck-Peccoz P, Persani L, Calebiro D, Bonomi M, Mannavola D, Campi I. Syndromes of hormone resistance in the hypothalamic-pituitary-thyroid axis. Best Pract Res Clin Endocrinol Metab 2006;20:529-46.

12. Amor AJ, Halperin I, Alfayate R, Borras VM, Escribano A, Gonzalez $\mathrm{C}$, et al. Identification of four novel mutations in the thyroid hormone receptor- $\beta$ gene in 164 Spanish and 2 Greek patients with resistance to thyroid hormone. Hormones (Athens) 2014;13:74-8.

13. Anselmo J, Refetoff $S$. Regression of a large goiter in a patient with resistance to thyroid hormone by every other day treatment with triiodothyronine. Thyroid 2004;14:71-4. 